\title{
Front Matter: Volume 11655
}

, "Front Matter: Volume 11655," Proc. SPIE 11655, Label-free Biomedical Imaging and Sensing (LBIS) 2021, 1165501 (14 April 2021); doi:

$10.1117 / 12.2596724$

SPIE. Event: SPIE BiOS, 2021, Online Only 


\title{
Label-free Biomedical Imaging and Sensing (LBIS) 2021
}

\author{
Natan T. Shaked \\ Oliver Hayden \\ Editors
}

6-11 March 2021

Online Only, United States

Sponsored and Published by

SPIE 
The papers in this volume were part of the technical conference cited on the cover and title page. Papers were selected and subject to review by the editors and conference program committee. Some conference presentations may not be available for publication. Additional papers and presentation recordings may be available online in the SPIE Digital Library at SPIEDigitalLibrary.org.

The papers reflect the work and thoughts of the authors and are published herein as submitted. The publisher is not responsible for the validity of the information or for any outcomes resulting from reliance thereon.

Please use the following format to cite material from these proceedings:

Author(s), "Title of Paper," in Label-free Biomedical Imaging and Sensing (LBIS) 2021, edited by Natan T. Shaked, Oliver Hayden, Proceedings of SPIE Vol. 11655 (SPIE, Bellingham, WA, 2021) Sevendigit Article CID Number.

ISSN: 1605-7422

ISSN: 2410-9045 (electronic)

ISBN: 9781510641457

ISBN: 9781510641464 (electronic)

Published by

SPIE

P.O. Box 10, Bellingham, Washington 98227-0010 USA

Telephone +1 3606763290 (Pacific Time) · Fax +1 3606471445

SPIE.org

Copyright (c) 2021, Society of Photo-Optical Instrumentation Engineers.

Copying of material in this book for internal or personal use, or for the internal or personal use of specific clients, beyond the fair use provisions granted by the U.S. Copyright Law is authorized by SPIE subject to payment of copying fees. The Transactional Reporting Service base fee for this volume is $\$ 21.00$ per article (or portion thereof), which should be paid directly to the Copyright Clearance Center (CCC), 222 Rosewood Drive, Danvers, MA 01923. Payment may also be made electronically through CCC Online at copyright.com. Other copying for republication, resale, advertising or promotion, or any form of systematic or multiple reproduction of any material in this book is prohibited except with permission in writing from the publisher. The CCC fee code is $1605-$ $7422 / 21 / \$ 21.00$.

Printed in the United States of America by Curran Associates, Inc., under license from SPIE.

Publication of record for individual papers is online in the SPIE Digital Library.

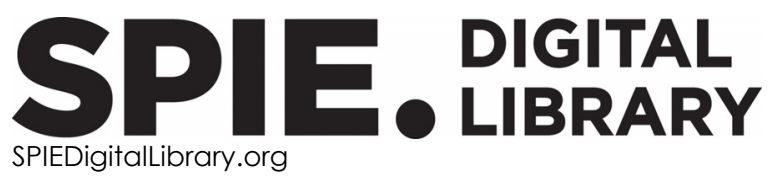

Paper Numbering: Proceedings of SPIE follow an e-First publication model. A unique citation identifier (CID) number is assigned to each article at the time of publication. Utilization of CIDs allows articles to be fully citable as soon as they are published online, and connects the same identifier to all online and print versions of the publication. SPIE uses a seven-digit CID article numbering system structured as follows:

- The first five digits correspond to the SPIE volume number.

- The last two digits indicate publication order within the volume using a Base 36 numbering system employing both numerals and letters. These two-number sets start with $00,01,02,03,04$, 05, 06, 07, 08, 09, 0A, OB ... 0Z, followed by 10-1Z, 20-2Z, etc. The CID Number appears on each page of the manuscript. 


\section{Contents}

AUTORUORESCENCE

1165507 Distinguishing cellular respiration vs. oxidative stress in turbid media using UV-excited autofluorescence spectrosc opy [11655-5]

DEFP LEARNING

1165509 Label-free detection of rare cancer cells using deep leaming and magnetic levitation principle [11655-10]

MULTISPECTRAL, DEEP UV, AND PHOTOACOUSTIC IMAGING

11655 OC Deep leaming-based virtual staining of label-free ultraviolet (UV) mic rosc opy images for hematological analysis [11655-13]

11655 OD Multispectral fluorescence imaging of ovanian tissue for the characterization and classification of early stage ovarian cancer [11655-14]

$11655 \mathrm{OH} \quad$ Label-free multi-spectral deep UV imaging of prostate cancer tissue [11655-18]

\section{OCTAND INTERFROMEIRY}

$116550 \mathrm{Q} \quad$ New model for understanding the relationship between tissue composition and photothemal optical coherence tomography signals [11655-26]

PHASE IMAGING

11655 OS Epi-illumination tomographic quantitative phase imaging identifies brain tumor margins [11655-28]

RAMAN IMAGING

1165513 Coherent anti-Stokes Raman spectroscopy enhanced by multiple overtone resonances (Invited Paper) [11655-45]

1165518 Raman mapping of transfemin and femitin distributions in breast cancercells [11655-44] 


\section{SPECTROSCOPY AND SCATIERING}

11655 1B Highly sensitive vibrational imaging by fluorescence detection of mid-infrared photothemal effect [11655-48]

$116551 \mathrm{C} \quad$ Optical and molecular longitudinal tracking of primary colorectal murine tumors shows differences in the angiogenic response to maximum-tolerated and metronomic approaches [11655-49]

11655 IG Progress toward a VUV Raman spectrometer to detect pathogens [11655-53]

\section{POSTER SESSION}

$116551 \mathrm{~K} \quad$ Automated detection of macrophages in quantitative phase images by deep leaming using a mask region-based convolutional neural network [11655-54] 